\title{
Potential Effects of an Invasive Nitrogen-Fixing Tree on a Hawaiian Stream Food Web ${ }^{1}$
}

\author{
Trisha B. Atwood, ${ }^{2,5}$ Tracy N. Wiegner, ${ }^{3}$ Jason P. Turner, ${ }^{3}$ and Richard A. MacKenzie ${ }^{4}$
}

\begin{abstract}
Falcataria moluccana (albizia) is an exotic nitrogen (N)-fixing tree currently invading riparian forests in Hawai' $i$, U.S.A. This study examined how this invasion is impacting stream ecosystems by using naturally occurring stable isotopes of carbon (C) and $\mathrm{N}$ to compare food web structure between a noninvaded and an albizia-invaded stream reach on the island of Hawai'i. Isotopic signatures of particulate organic matter (POM), macroalgae, invertebrates, and fishes were collected and compared between the two stream reaches. Stable C isotopic signatures of organic matter sources (POM and macroalgae) and consumers (amphipods, caddisflies, crayfish, and fishes) from the invaded site were depleted in ${ }^{13} \mathrm{C}$ compared with the noninvaded site. In contrast, all samples from the invaded site were enriched in ${ }^{15} \mathrm{~N}$ compared with the noninvaded site. Results from IsoSource and two-source mixing models suggested that albizia was a major contributor to diets of lower-level consumers within the invaded site, displacing POM and macroalgae as their major food sources. Albizia was also an indirect $\mathrm{C}$ and $\mathrm{N}$ source for higher-level consumers within the invaded site because albizia was the major dietary constituent of their prey. In addition, ${ }^{15} \mathrm{~N}$ enrichment of the macroalgae at the invaded site suggests that albizia may be an important $\mathrm{N}$ source to benthic primary producers and could be further altering the food web from bottom up. Our study provides some of the first evidence that invasive riparian $\mathrm{N}$-fixing trees can potentially alter the structure of stream food webs.
\end{abstract}

The PRESENCE of nitrogen (N)-fixing plants in forests can greatly impact nutrient cycling and affect the export of $\mathrm{N}$ from watersheds through shedding and decomposition of their $\mathrm{N}$-rich leaves on the forest floor (Binkley

\footnotetext{
${ }^{1}$ Funding was provided by a Seed Grant awarded to J.P.T. by the University of Hawai'i at Hilo Research Council. Manuscript accepted 18 August 2009.

${ }^{2}$ Department of Forest Sciences, University of British Columbia, 3041-2424 Main Mall, Vancouver, British Columbia V6T 1Z4, Canada.

${ }^{3}$ Marine Science Department, University of Hawai' $i$ at Hilo, 200 West Kāwili Street, Hilo, Hawai'i 96720.

${ }^{4}$ U.S. Department of Agriculture Forest Service, Institute of Pacific Islands Forestry, 60 Nowelo Street, Hilo, Hawai'i 96720.

${ }^{5}$ Corresponding author (e-mail: trishaa@interchange .ubc.ca).
}

Pacific Science (2010), vol. 64, no. 3:367-379

doi: $10.2984 / 64.3 .367$

(C) 2010 by University of Hawai'i Press

All rights reserved et al. 1992, Compton et al. 2003, Scott et al. 2008). In some instances, $\mathrm{N}$ inputs from $\mathrm{N}$ fixing plants can be substantial and can exceed industrial $\mathrm{N}$ inputs (Wright and Rasmussen 1998). Excess $N$ inputs to soils can result in $\mathrm{N}$-saturation, a condition where excess $\mathrm{N}$ in soils can leach into nearby streams, lakes, and groundwater (Aber et al. 1989). Thus, the invasion of $\mathrm{N}$-fixing trees in watersheds could substantially alter $\mathrm{N}$ dynamics and ecosystem functions of both the forest and stream. For example, colonization of logged regions by the native $\mathrm{N}$-fixing Alnus rubra (red alder), an early successional species, in the Pacific Northwest of the United States resulted in increased concentrations of nitrate $\left(\mathrm{NO}_{3}^{-}\right)$and dissolved organic $\mathrm{N}(\mathrm{DON})$ in streams from leaching of $\mathrm{N}$ from soils (Compton et al. 2003). $\mathrm{N}$ from alder has also been shown to stimulate primary production, fungal activity, and rates of leaf litter breakdown in streams (Goldman 1961, Volk et al. 2003, Ferreira et al. 2006, Gulis et al. 2006), 
and increased leaf litter inputs increased stream invertebrate abundances (Piccolo and Wipfli 2002, Wipfli and Gregovich 2002). Studies in the Pacific Northwest suggest that invasive $\mathrm{N}$-fixing trees could impact stream food webs, but few studies have examined the role of leaves from $\mathrm{N}$-fixing trees as a food resource to stream organisms or how invasive $\mathrm{N}$-fixing trees may be changing food web structure of invaded streams. In addition, to our knowledge, no studies to date have examined the impacts of invasive $\mathrm{N}$-fixing trees on tropical streams that are often $\mathrm{N}$-limited (Laperriere 1995, Neill et al. 2001).

Falcataria moluccana (albizia), an N-fixing tree native to the Moluccas, New Guinea, New Britain, and the Solomon Islands (Wagner et al. 1999), has invaded riparian forests throughout the tropical western Pacific region. In Hawai'i, U.S.A., it was introduced from 1920 to 1950 to reforest degraded watersheds and as an ornamental (Nelson 1965). Owing to its ability to fix atmospheric $\mathrm{N}$ in $\mathrm{N}$-limited environments such as Hawai' $\mathrm{i}$ Island (Vitousek 2004) and its high growth rate, albizia has become an established species in Hawaiian forests (Asner et al. 2008). Within these forests, it has been reported to significantly increase $\mathrm{N}$ inputs to soils through decomposition of its N-rich leaves on the forest floor (Hughes and Denslow 2005), which may be leading to the observed increases in $\mathrm{NO}_{3}^{-}$concentrations of streams draining albizia stands (R. F. Hughes, T.N.W., L. M. Shizuma, D. K. Bushaw, and M. E. Manuel, unpubl. data). Increased inputs of leaves from these highly productive and invasive $\mathrm{N}$-fixing trees may also be a more valuable food source than native riparian leaf litter due to the higher $\mathrm{N}$ content in the leaves of $\mathrm{N}$-fixing trees (e.g., Wallace et al. 1997). Therefore, leaf litter inputs from invasive riparian $\mathrm{N}$-fixing trees may change the food web structure of tropical streams from autochthonous-based to allochthonousbased, especially because inputs of native leaf litter do not appear to be an important food source for stream organisms (Larned et al. 2000).

Natural abundance stable isotope analysis is a tool that can be used to examine food web alterations caused by invasive species (Vander Zanden et al. 1999). Isotopic composition of an organism's tissue is representative of its average diet and can reflect both longand short-term food resources (Peterson and Fry 1987). Use of a dual stable isotope analysis of both carbon (C) and N can help identify important sources of organic matter and trophic positions of organisms in a food web. If $\delta^{13} \mathrm{C}$ signatures are distinct among primary producers and exhibit minimal fractionation $(0-1 \%$ ) from prey to predator (Fry and Sherr 1984, Maguire and Grey 2006, McCarthy et al. 2006), then $\delta^{13} \mathrm{C}$ signatures can be used to determine the importance of an organic matter source to a consumer. Unlike $\delta^{13} \mathrm{C}$ signatures, $\delta^{15} \mathrm{~N}$ signatures become enriched $2.5-3.5 \%$ from prey to predator due to the excretion of the lighter isotope during physiological processes (Fry and Sherr 1984). This predictable change in $\delta^{15} \mathrm{~N}$ signatures allows estimation of consumers' trophic positions and delineation of food webs (Cabana and Rasmussen 1996). In addition to its use as a trophic-level indicator, $\delta^{15} \mathrm{~N}$ signatures of $\mathrm{N}$-fixing plant leaves can also be used to understand the importance of this foliage as an organic matter source to consumers (Peterson and Fry 1987). This is possible because $\mathrm{N}$-fixing plants have distinctly different $\delta^{15} \mathrm{~N}$ signatures due to their ability to obtain $\mathrm{N}$ from the atmosphere, rather than from the soils like most plants.

Many stream habitats in the Hawaiian Islands have undergone substantial habitat alterations as a result of development, including the removal of the riparian canopy and channelization (Brasher 2003). Although the removal of the canopy is likely to cause changes to stream community composition through higher stream temperatures, greater daily temperature fluctuations, increased turbidity, and decreased microhabitats (Brasher 2003 ), it is not likely to change the autochthonous nature of these streams' food webs. However, along some streams, small riparian areas exist, which are generally composed of nonnative trees, such as albizia (Cuddihy and Stone 1990). These trees, if they have prolific litter production and their litter is rich in $\mathrm{N}$, like albizia, may have the potential to shift 
Hawaiian stream food webs from being algalbased to leaf litter-based. The objective of our study was to determine how the invasion of the riparian zone by an $\mathrm{N}$-fixing tree, albizia, alters food web structure in a suburban, first-order Hawaiian stream. Here, we hypothesized that albizia leaf litter would be incorporated into the aquatic food web and that the base of the food web would shift from being autochthonous-based to allochthonous-based in the presence of albizia. To test our hypothesis, we compared diets of stream consumers and the food web structure between a noninvaded upstream reach and an albizia-invaded downstream reach using stable $\mathrm{C}$ and $\mathrm{N}$ isotopic signatures.

\section{MATERIALS AND METHODS}

\section{Site Description}

To evaluate the impact of albizia on a stream food web, stream characteristics needed to be as similar as possible between study sites. Therefore, we evaluated the impact of albizia on a single stream where the stream characteristics and watershed land-use histories were comparable between sites, except for the riparian vegetation. The stream selected was 'Ainako stream, which is located in the city of Hilo, Hawai'i. This stream was the best example of a stream with a noninvaded upper reach and a densely invaded lower reach out of all the streams we surveyed as potential sites for this study. "Ainakō stream is a first-order, perennial, suburban stream that is sustained by groundwater and is a tributary of the Wailuku River, the largest perennial river in the state of Hawai' $i$ (Juvik and Juvik 1998). Two study sites within 'Ainakō stream were selected in reaches above and within a riparian forest invaded by albizia. Both sites are located on a 1984 lava flow and have similar land-use histories. The noninvaded reach was located in the upper portion of the stream at an elevation of $217 \mathrm{~m}$ and was directly below the source of the groundwater. Land use at this site is residential, and the riparian zone is almost completely devoid of trees. There are also no albizia trees located at this site or upstream from it. The invaded reach was located 1.8 $\mathrm{km}$ downstream from the noninvaded reach at an elevation of $126 \mathrm{~m}$ and is the nearest accessible stream site to the upper site with an extensive albizia canopy. Land use at the lower site is also residential; however, there is a narrow $(5-10 \mathrm{~m})$ riparian forest consisting primarily of albizia trees. In addition, the total dissolved nitrogen and $\mathrm{NO}_{3}^{-}$concentrations were three times higher than those measured at the noninvaded site, and the $\delta^{15} \mathrm{~N}$ isotopic signature of the $\mathrm{NO}_{3}^{-}$pool was twice as enriched in ${ }^{15} \mathrm{~N}$ (Table 1), suggesting that albizia may be affecting the water chemistry at this site (R. F. Hughes, T.N.W., L. M. Shizuma, D. K. Bushaw, and M. E. Manuel, unpubl. data).

\section{Sample Collection}

Flora and fauna were collected from all three major stream substrate types (boulder, gravel, and silt) and habitat units (run, riffle, and pool) within both stream reaches in August 2006. Water column particulate organic matter (POM) was collected using a $20 \mu \mathrm{m}$ mesh plankton net, and all leaves and woody debris were removed from the sample. Albizia leaves from the invaded site were collected from trees along both sides of the stream bank and were rinsed thoroughly to remove all terrestrial insects. Although Melaleuca quinquenervia (paperbark), Psidium cattleianum (strawberry guava), Syzygium jambos (rose apple), and native Metrosideros polymorpha ('ōhi'a lehua) can be found several kilometers above the noninvaded site in a boglike area near the groundwater seep, only a very small and insignificant amount of leaf litter was found within the stream channel at this site. Thus, leaf litter was not collected as a possible food source from the noninvaded site. Chlorophyta macroalgae, Cheumatopsyche analis (caddisflies), and Hyallela sp. amphipods were scraped off rocks using a soft-bristle brush into a $500 \mu \mathrm{m}$ mesh plankton net and later separated. Adult and juvenile Procambarus clarkii (American swamp crayfish), Xiphophorus belleri (swordtails), and Poecilia reticulata (guppies) were sampled using dip nets. All 
samples were stored frozen until prepared for stable isotope analysis.

\section{Stable Isotope Analysis}

POM, macroalgae, amphipods, C. analis, and muscle tissue samples from adult and juvenile $P$. clarkii, $X$. belleri, and $P$. reticulata were dried at $70^{\circ} \mathrm{C}$ for a minimum of $48 \mathrm{hr}$. Dried samples were homogenized using a mortar and pestle, weighed, packed into tin capsules, and analyzed for $\delta^{13} \mathrm{C}$ and $\delta^{15} \mathrm{~N}$ using an analyzer (Costech Elemental Analyzer Conflo III) coupled to an isotope ratio mass spectrometer (Thermo Delta V Advantage). Stable isotope signatures were calculated as follows: $\delta X(\%)=\left(\left[R_{\text {sample }} / R_{\text {standard }}\right]-1\right) 1,000$, where $X$ is ${ }^{13} \mathrm{C}$ or ${ }^{15} \mathrm{~N}$ and $R$ is ${ }^{13} \mathrm{C}:{ }^{12} \mathrm{C}$ or ${ }^{15} \mathrm{~N}:{ }^{14} \mathrm{~N}$. Results are presented as deviations from a standard (V-PDB for $\delta^{13} \mathrm{C}$ and atmospheric $\mathrm{N}_{2}$ for $\delta^{15} \mathrm{~N}$ ) and reported as $\delta^{13} \mathrm{C}$ and $\delta^{15} \mathrm{~N}$ in parts per thousand (\%).

\section{Food Web Analysis}

Quantifying dietary contribution of multiple prey types to a euryphagous diet is beyond the limits of traditional two-source mixing models (Phillips and Gregg 2003). To overcome these limitations, we used IsoSource software (Version 1.3.1, Microsoft Visual Basic) to calculate the contribution of up to seven possible dietary sources (Phillips and Gregg 2003). Before contributions were determined, mean trophic fractionations of $1 \%$ $\mathrm{C}$ and $3 \% \mathrm{~N}$ were subtracted from the consumers' stable isotope signatures (Fry and Sherr 1984). Contributions of each endmember were determined using a source increment of $1 \%$. Tolerance levels ranged from 0.001 to 2.0 and fall within those currently reported in the literature (e.g., Mantel et al. 2004). Although this can result in greater uncertainty, it allowed consumers' signatures to fall within the polygon created by the $\delta^{13} \mathrm{C}$ and $\delta^{15} \mathrm{~N}$ signatures of food sources. A two-source mixing model modified from Rooker et al. (2006) was used for primary consumers collected within the noninvaded reach (amphipods and $C$. analis) 
TABLE 2

Wilcoxon Rank-Sum Results for $\delta^{13} \mathrm{C}, \delta^{15} \mathrm{~N}$, and Sample Size $(n)$ of Samples (Where J Represents the Juvenile Age Class of That Species) Collected from a Noninvaded Downstream Reach and a Falcataria moluccana-Invaded Upstream Reach in 'Ainakō Stream, Hawai'i

\begin{tabular}{lcccc}
\hline \hline Samples & Noninvaded Site $n$ & Invaded Site $n$ & $\delta^{13} \mathrm{C} P$-Value & $\delta^{15} \mathrm{~N} P$-Value \\
\hline POM & 9 & 10 & 0.079 & $<0.001$ \\
Macroalgae & 5 & 5 & 0.008 & 0.008 \\
Amphipoda & 5 & 5 & 0.016 & 0.286 \\
Cheumatopsyche analis & 5 & 5 & 0.008 & 0.008 \\
Poeciliids (J) & 3 & 5 & 0.100 & 0.100 \\
Poecilia reticulata & 5 & 6 & 0.286 & 0.001 \\
Xiphophorus helleri & 1 & 3 & 0.100 & 0.286 \\
Procambarus clarkii $(\mathrm{J})$ & 3 & 8 & 0.002 & 0.100 \\
Procambarus clarkii & 5 & & & 0.002 \\
\hline
\end{tabular}

where only two possible food sources (POM and macroalgae) were sampled.

\section{Statistical Analysis}

Data were statistically analyzed using S-Plus Statistical Software (Version 8.0, Insightful Corp., 2006). Due to small sample size, a series of nonparametric Wilcoxon rank-sum tests were used to determine statistically significant differences in $\delta^{13} \mathrm{C}$ and $\delta^{15} \mathrm{~N}$ signatures of individual organic matter sources and consumers between sites.

\section{RESULTS}

\section{Stable Isotope Analysis}

Stable C isotopic signatures of both primary producers and consumers were more depleted in the heavier isotopes, and stable $\mathrm{N}$ isotopic signatures were enriched at the invaded site compared with the noninvaded site. $\delta^{13} \mathrm{C}$ signatures of macroalgae, amphipods, $C$. analis, $P$. reticulata, and adult $P$. clarkii from the invaded site were significantly more depleted in ${ }^{13} \mathrm{C}$ by $1.5 \% 0-7.0 \%$ compared with the noninvaded site (Table 2, Figure $1 A$ ). This trend was also observed in POM, poeciliids, and juvenile $P$. clarkii but was not significant (Table 2, Figure $1 A$ ). The $\delta^{15} \mathrm{~N}$ signatures of the POM, macroalgae, C. analis, P. reticulata, and adult $P$. clarkii from the invaded site were significantly more enriched in ${ }^{15} \mathrm{~N}$ by $1.5 \% 0-2.0 \%$ compared with the noninvaded site (Table 2, Figure $1 B$ ). Although this trend was observed for amphipods, juvenile poeciliids, $X$. belleri, and juvenile $P$. clarkii, no significant difference between sites was detected (Table 2, Figure 1B).

\section{Food Web Analysis}

Trophic-level analyses of amphipods and $C$. analis indicated that their diets were mainly composed of primary producers, and that they were primary consumers within both the noninvaded and invaded sites (Figure $2 \mathrm{~A}$ and $B$ ). In the absence of albizia, two-source mixing models indicated that POM composed $\sim 50 \%$ of $C$. analis diets and $<10 \%$ of amphipod diets, and macroalgae composed $\sim 60 \%$ and $>90 \%$, respectively (Table 3 ). IsoSource revealed that the diets of $C$. analis and amphipods collected from the invaded site were supported by a mixture of albizia, POM, and macroalgae (Table 4). Results show that albizia was a dominate food source for both $C$. analis and amphipods, contributing between $73 \%$ and $81 \%$ and $31 \%$ and $73 \%$, respectively. Contributions of POM and macroalgae were not as important as albizia as a food source at the invaded site; POM contributed $0 \%-28 \%$ and $0 \%-49 \%$ to amphipods and $C$. analis diets, respectively, and macroalgae contributed $0 \%-27 \%$ and $0 \%-69 \%$, respectively.

Poecilia reticulata, $X$. belleri, and juvenile poeciliids were identified as secondary con- 

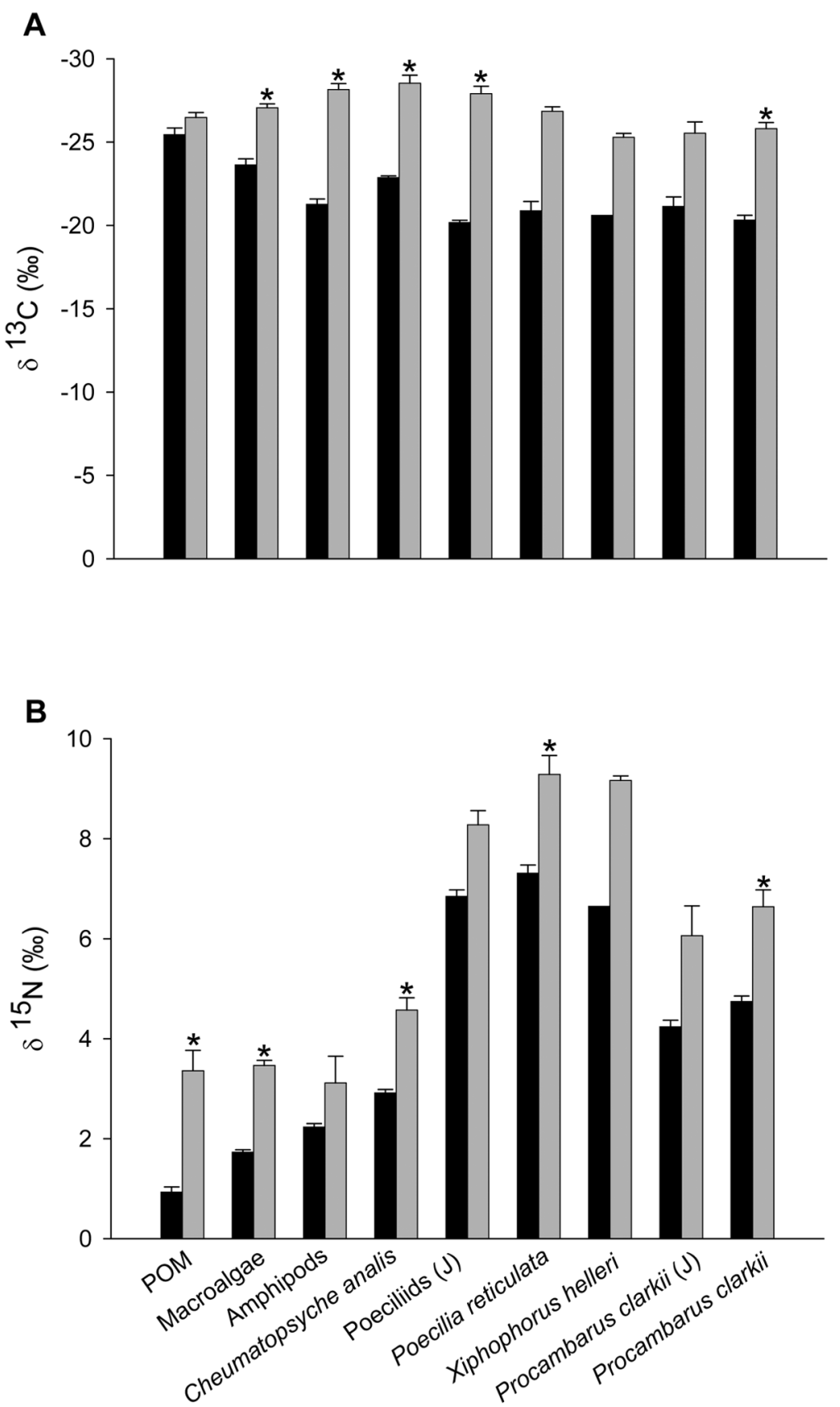

FigURE 1. Mean $( \pm \mathrm{SE})(A) \delta^{13} \mathrm{C}$ and $(B) \delta^{15} \mathrm{~N}$ isotopic signatures of sources of organic matter and consumers (where $\mathrm{J}$ represents the juvenile age class of that species) collected within the noninvaded and Falcataria moluccana-invaded stream reaches in 'Ainakō stream, Hawai'i. Significant differences based on Wilcoxon rank-sum analyses are indicated by *. 


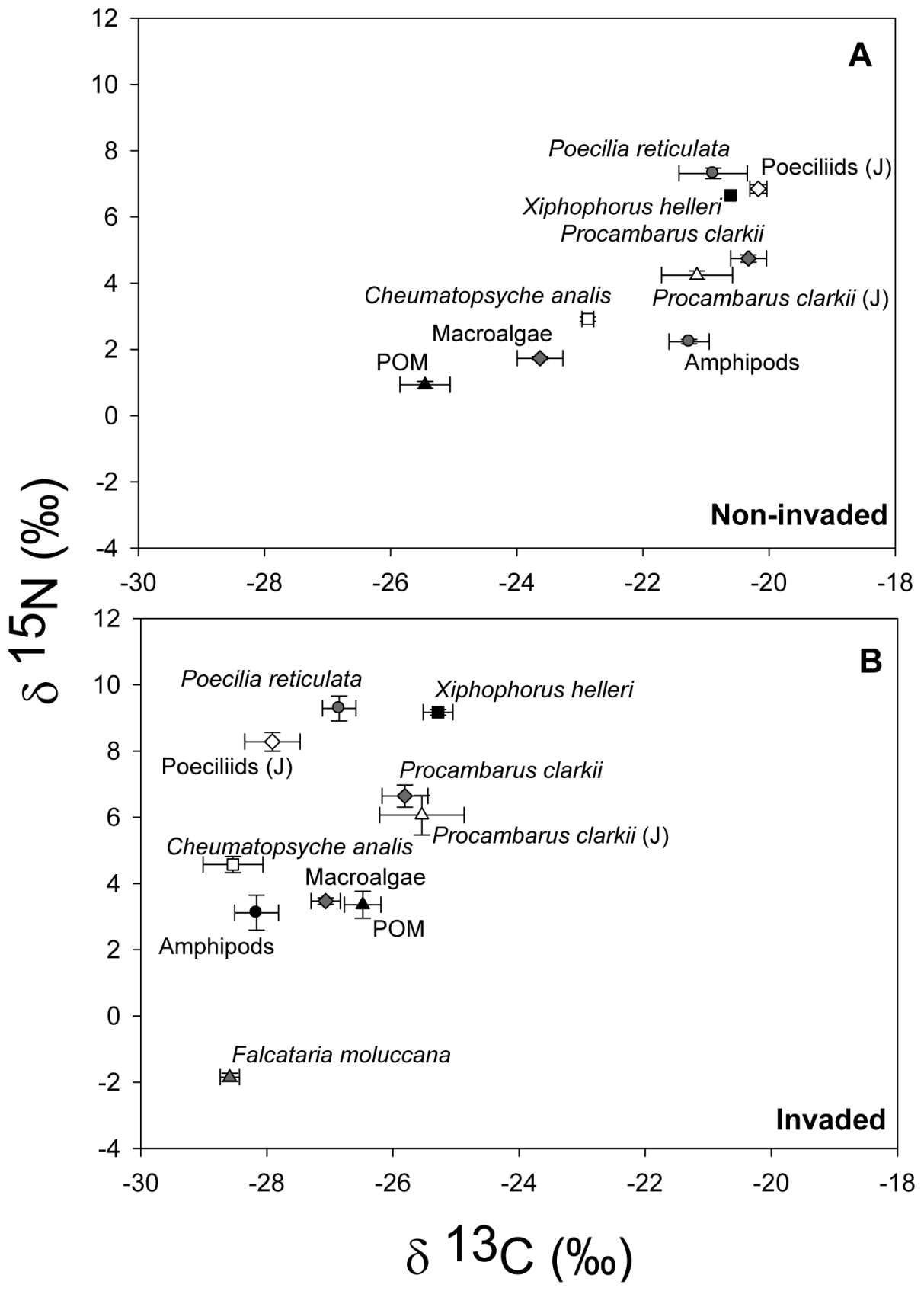

Figure 2. Scatterplot of mean $( \pm \mathrm{SE}) \delta^{13} \mathrm{C}$ and $\delta^{15} \mathrm{~N}$ isotopic signatures of sources of organic matter and consumers (where $\mathrm{J}$ represents the juvenile age class of that species) collected from the $(A)$ noninvaded and $(B)$ Falcataria moluccana-invaded stream reaches in 'Ainakō stream, Hawai' $i$. 
TABLE 3

Dietary Contributions Determined from IsoSource and Two-Source Mixing Models for Noninvaded Stream Reach Consumers (Where J Represents the Juvenile Age Class of That Species) Collected in 'Ainakō Stream, Hawai'i

\begin{tabular}{|c|c|c|c|c|c|c|c|}
\hline \multirow[b]{2}{*}{ Diets } & \multicolumn{7}{|c|}{ Consumers } \\
\hline & Amphipoda & Cheumatopsyche analis & Xiphophorus helleri & Poecilia reticulata & Poeciliids (J) & Procambarus clarkii $(\mathrm{J})$ & Procambarus clarkii \\
\hline POM & $<10 \%$ & $\sim 50 \%$ & $0 \%-5 \%$ & $0 \%-5 \%$ & $0 \%-15 \%$ & $0 \%-48 \%$ & $0 \%-14 \%$ \\
\hline Macroalgae & $>90 \%$ & $\sim 60 \%$ & $0 \%-10 \%$ & $0 \%-8 \%$ & $0 \%-31 \%$ & $0 \%-83 \%$ & $0 \%-24 \%$ \\
\hline Amphipoda & - & - & $15 \%-39 \%$ & $0 \%-14 \%$ & $12 \%-83 \%$ & $8 \%-100 \%$ & $73 \%-100 \%$ \\
\hline Cheumatopsyche analis & - & - & $61 \%-85 \%$ & $86 \%-100 \%$ & $17 \%-88 \%$ & $0 \%-49 \%$ & $0 \%-15 \%$ \\
\hline Xiphophorus helleri & - & - & - & - & - & $0 \%-13 \%$ & $0 \%-4 \%$ \\
\hline Poecilia reticulata & - & - & - & - & - & $0 \%-11 \%$ & $0 \%-3 \%$ \\
\hline IsoSource tolerance level & - & - & 1.0 & 1.5 & 1.5 & 1 & 0.5 \\
\hline
\end{tabular}

TABLE 4

Dietary Contributions Determined from IsoSource Mixing Models for Falcataria moluccana-Invaded Stream Reach Consumers (Where J Represents the Juvenile Age Class of That Species) Collected in 'Ainakō Stream, Hawai'i

\begin{tabular}{|c|c|c|c|c|c|c|c|}
\hline \multirow[b]{2}{*}{ Diets } & \multicolumn{7}{|c|}{ Consumers } \\
\hline & Amphipoda & Cheumatopsyche analis & Xiphophorus helleri & Poecilia reticulata & Poeciliids (J) & Procambarus clarkii $(\mathrm{J})$ & Procambarus clarkii \\
\hline Falcataria moluccana & $73 \%-81 \%$ & $31 \%-73 \%$ & $0 \%-3 \%$ & $0 \%-4 \%$ & $0 \%-4 \%$ & $4 \%-7 \%$ & $0 \%-13 \%$ \\
\hline POM & $0 \%-20 \%$ & $0 \%-49 \%$ & $0 \%-33 \%$ & $0 \%-24 \%$ & $0 \%-24 \%$ & $85 \%-96 \%$ & $43 \%-83 \%$ \\
\hline Macroalgae & $0 \%-27 \%$ & $0 \%-69 \%$ & $0 \%-36 \%$ & $0 \%-26 \%$ & $0 \%-26 \%$ & $0 \%-10 \%$ & $0 \%-53 \%$ \\
\hline Amphipoda & - & - & $0 \%-20 \%$ & $0 \%-20 \%$ & $0 \%-19 \%$ & $0 \%-4 \%$ & $0 \%-17 \%$ \\
\hline Cheumatopsyche analis & - & - & $64 \%-87 \%$ & $75 \%-100 \%$ & $74 \%-100 \%$ & $0 \%-2 \%$ & $0 \%-15 \%$ \\
\hline Xiphophorus helleri & - & - & - & - & - & $0 \%-2 \%$ & $0 \%-16 \%$ \\
\hline Poeciliids (J) & - & - & - & - & - & $0 \%-2 \%$ & $0 \%-16 \%$ \\
\hline IsoSource tolerance level & 1 & 2 & 2 & 2 & 1 & 0.1 & 0.001 \\
\hline
\end{tabular}


sumers for both the noninvaded and invaded sites because trophic-level analysis indicated that their diets were composed of primary producers and primary consumers (Figure $2 A$ and $B$ ). Within the noninvaded site, $C$. analis was the major contributor to the diets of the three fish taxa collected (P. reticulata: $86 \%-100 \%, X$. belleri: $61 \%-85 \%$, and poeciliids: $17 \%-88 \%$ ), with the remainder of their diets consisting of macroalgae and POM (Table 3). Diets of all three of the fish taxa collected from the invaded site were similar to one another, consisting of $C$. analis, macroalgae, POM, amphipods, and albizia (Table 4), with $C$. analis being the dominant dietary contributor (P. reticulata: $75 \%-$ $100 \%$, X. belleri: $64 \%-87 \%$, and poeciliids: $74 \%-100 \%)$. POM, macroalgae, and amphipod contributions to the diets of all three fish taxa were relatively similar (Table 4). Albizia was only a minor contribution to the diets of the fish taxa (P. reticulata: $0 \%-4 \%$, $X$. belleri: $0 \%-3 \%$, and poeciliids: $0 \%-4 \%)$.

Trophic-level position for adult and juvenile $P$. clarkii indicated that their diets were composed of primary producers and primary consumers, identifying them as secondary consumers for both the noninvaded and invaded sites (Figure $2 A$ and $B$ ). Diets of both adult and juvenile $P$. clarkii within the noninvaded site were dominated by amphipods (adults: $73 \%-100 \%$ and juveniles: $8 \%-$ $100 \%)$. However, remaining dietary contributions of the two age classes of $P$. clarkii varied (Table 3). Diets of adult and juvenile $P$. clarkii collected from the invaded site were similar to each other in that the major contributor to their diets was POM (adults: $85 \%-96 \%$ and juveniles: $43 \%-83 \%$ ), and albizia had only a minimal contribution (adults: $0 \%-13 \%$ and juveniles: $4 \%-7 \%)$. However, the remaining dietary contributions of macroalgae, $C$. analis, amphipods, and fishes varied between the two age classes of $P$. clarkii collected (Table 4).

\section{DISCUSSION}

Leaf litter can be a major source of energy to heterotrophic food webs in streams with extensive riparian forests (Webster et al. 1999).
Thus, plant species invading riparian zones are capable of substantially altering stream food webs. Results from our study indicated that invasion of the riparian forest of 'Ainakō stream by albizia on Hawai'i Island may have altered its food web by directly contributing to the diets of primary and secondary consumers. Results show that albizia was a major contributor to diets of amphipods and C. analis, displacing POM and macroalgae as the major food source within the invaded site. However, albizia contributed only a minor portion to diets of adult and juvenile $P$. clarkii. Although the major contributor to the diets of adult and juvenile $P$. clarkii varied from an amphipod-dominated diet in the noninvaded site to a POM-dominated diet in the invaded site, this shift could not be explained by the absence or presence of albizia. Finally, although albizia's direct contribution to the diets of $P$. reticulata, $X$. helleri, and poeciliids was minor, it was an indirect $\mathrm{C}$ and $\mathrm{N}$ source to these organisms because it was the main component of the diets of amphipods and $C$. analis, the dominant food sources of these fishes within the invaded site.

Depleted $\delta^{13} \mathrm{C}$ signatures of consumers in the invaded site can be partially explained by feeding on ${ }^{13} \mathrm{C}$-depleted albizia leaves, especially for amphipods and $C$. analis (Figure $2 B)$. However, macroalgae were also a potential food source (Table 2), which may have contributed to the depleted $\delta^{13} \mathrm{C}$ signatures of consumers in the invaded site because algal $\delta^{13} \mathrm{C}$ signatures were depleted in that reach compared with the noninvaded reach (Figure $2 B)$. Spatial variability in algal $\delta^{13} \mathrm{C}$ was likely due to several factors including differences in ${ }^{13} \mathrm{C}$ fractionation between algal species assemblages (Blade et al. 2006) and $\mathrm{CO}_{2}$ sources (Maberly et al. 1992). Differences may have also been due to variation in concentration or $\delta^{13} \mathrm{C}$ signatures of dissolved inorganic carbon between sites (Finlay 2001, 2004). Although consumer densities were not measured, higher observed consumer densities at the invaded site could have increased dissolved inorganic carbon levels from their respiration and depleted the algal $\delta^{13} \mathrm{C}$ signatures (Finlay 2004). Algal $\delta^{13} \mathrm{C}$ values are also positively correlated with algal growth 
rates (e.g., Finlay 2001) and negatively correlated with stream velocities (e.g., Finlay et al. 1999). However, observed algal biomass was higher and stream velocity was generally lower in the invaded reach (Table 1), which should have resulted in more enriched, not depleted algal $\delta^{13} \mathrm{C}$ signatures. These patterns may be attributed to the fact that algal biomass observations were made at only one time point and that velocities were lower by only 0.05 to $0.10 \mathrm{~m} / \mathrm{sec}$, an order of magnitude lower than values reported in the literature (Finlay et al. 1999). Clearly, more work is needed to understand $\delta^{13} \mathrm{C}$ patterns reported here.

Albizia may also be an important source of $\mathrm{N}$ to benthic primary producers within the invaded reach of 'Ainakō stream. High rates of N-fixation by red alder in the Pacific Northwest substantially increased total dissolved nitrogen and $\mathrm{NO}_{3}^{-}$concentrations in neighboring aquatic ecosystems, resulting in increased rates of primary production within those systems (Goldman 1961, Compton et al. 2003). In 'Ainakō stream, total dissolved nitrogen and $\mathrm{NO}_{3}^{-}$concentrations are higher in the reach with albizia, suggesting that the trees may be contributing $\mathrm{N}$ to the stream. There are two possible processes by which albizia may be increasing stream $\mathrm{N}$ concentrations: (1) mineralization of leaf litter by microbes and fungal organisms within the stream (Webster et al. 1999), or (2) chemical leaching within riparian soils and lateral groundwater transport (Wondzell and Swanson 1996). To date, the occurrence and extent to which these processes are occurring within the stream channel or riparian soil of 'Ainakō stream have not been determined. Thus, the mechanism by which $\mathrm{N}$ from albizia becomes available to primary producers within the stream is currently unknown.

Results from our study showed that the $\delta^{15} \mathrm{~N}$ isotopic signature of macroalgae collected within the invaded site was significantly more enriched in ${ }^{15} \mathrm{~N}$ compared with the noninvaded site. One possible explanation for this enrichment is reverse fractionation, where ${ }^{15} \mathrm{~N}$ is selected over ${ }^{14} \mathrm{~N}$ during the assimilation of ammonium $\left(\mathrm{NH}_{4}^{+}\right)($Cohen and
Fong 2005). This type of fractionation has been documented in Enteromorpha intestinalis, an estuarine Chlorophyta macroalga, although the physiological explanation for this has not yet been determined (Cohen and Fong 2005). However, this hypothesis assumes that macroalgae is preferentially taking up $\mathrm{NH}_{4}^{+}$derived from albizia as opposed to $\mathrm{NO}_{3}^{-}$. Another explanation is that the $\delta^{15} \mathrm{~N}$ of $\mathrm{N}$ assimilated by macroalgae was enriched through the process of denitrification, which could occur in the anoxic soils within the riparian zone and/or in anoxic zones within the stream converting $\mathrm{NO}_{3}^{-}$and $\mathrm{NO}_{2}^{-}$produced from albizia leaf litter to ${ }^{15} \mathrm{~N}$-depleted $\mathrm{N}_{2}$, resulting in ${ }^{15} \mathrm{~N}$ enrichment of the remaining $\mathrm{NO}_{3}^{-}$(Bedard-Haughn et al. 2003). This ${ }^{15} \mathrm{~N}$-enriched $\mathrm{NO}_{3}^{-}$would then be available to leach into the stream, where it could be taken up by primary producers, enriching their signatures and leading to an overall enrichment of the food web from bottom up. However, to fully understand the impact of albizia on aquatic systems, further research is needed to determine the presence and extent of microbial $\mathrm{N}$ processing within the riparian zone and stream, and its associated isotopic fractionation.

\section{CONCLUSIONS}

Understanding impacts of invasive species is imperative for management efforts in terrestrial and aquatic ecosystems. Albizia poses a threat to Hawaiian ecosystems because it is altering important ecosystem processes in both terrestrial (Hughes and Denslow 2005) and aquatic environments. Our study, in conjunction with previous work (Hughes and Denslow 2005), demonstrates that albizia can have cross-ecosystem impacts, where its presence in the riparian zone could cause stream food webs to change from being autochthonous-based to allochthonous-based. In addition, results from concurrent research in 'Ainakō stream (R. F. Hughes, T.N.W., L. M. Shizuma, D. K. Bushaw, and M. E. Manuel, unpubl. data) suggest that albizia may increase the amount of biologically available $\mathrm{N}$ in Hawaiian streams, which could 
stimulate algal production and further alter the stream food web and community composition through increased densities of herbivorous organisms. A transition from an autochthonous-based to an allochthonousbased food web coupled with increased $\mathrm{N}$ availability may make streams with an albizia-invaded riparian zone more susceptible to future invasions by aquatic species.

As invasive species continue to spread, threatening biodiversity and ecosystem functions, we need to better understand how they impact ecosystems to better control and ultimately eradicate them. Results from our study provide insights into the effects of invasive and native $\mathrm{N}$-fixing plants on aquatic food webs, but our study was conducted on a single stream at a single point in time. Therefore, more research is needed to determine if the effect we observed is consistent among sites and different species of $\mathrm{N}$-fixing plants.

\section{ACKNOWLEDGMENTS}

We thank Randi Schneider and the University of Hawai'i at Hilo analytical laboratory for isotope analyses, Flint Hughes for his comments on an early draft of the manuscript, Mark Manuel for water-chemistry data, and Levi McWhorter and Trisann Bambico for help with sample collection and processing.

\section{Literature Cited}

Aber, J. D., K. J. Nadelhoffer, P. Steudler, and J. M. Melillo. 1989. Nitrogen saturation in northern forest ecosystems. BioScience 39:378-386.

Asner, G. P., R. F. Hughes, P. M. Vitousek, D. E. Knapp, T. Kennedy-Bowdoin, J. Boardman, R. E. Martin, M. Eastwood, and R. O. Green. 2008. Invasive plants transform the three-dimensional structure of rain forests. Proc. Natl. Acad. Sci. U.S.A. 105:4519-4523.

Bedard-Haughn, A., J. W. van Groenigen, and C. van Kessel. 2003. Tracing ${ }^{15} \mathrm{~N}$ through landscapes: Potential uses and precautions. J. Hydrol. 272:175-190.
Binkley, D., P. Sollins, R. Bell, D. Sachs, and D. Myrold. 1992. Biogeochemistry of adjacent conifer and alder-conifer stands. Ecology 73:2022-2033.

Blade, D. L., M. L. Pace, J. J. Cole, and S. R. Carpenter. 2006. Can algal photosynthetic inorganic carbon isotope fractionation be predicted in lakes using existing models? Aquat. Sci. 68:142-153.

Brasher, A. M. D. 2003. Impacts of human disturbances on biotic communities in Hawaiian streams. BioScience 53:10521060.

Cabana, G., and J. Rasmussen. 1996. Comparison of aquatic food chains using nitrogen isotopes. Ecology 93:10844-10847.

Cohen, R. A., and P. Fong. 2005. Experimental evidence supports the use of $\delta^{15} \mathrm{~N}$ content of the opportunistic green macroalgae Enteromorpha intestinalis (Chlorophyta) to determine nitrogen source to estuaries. J. Phycol. 41:287-293.

Compton, J. E., M. B. Church, S. T. Larned, and W. E. Hogsett. 2003. Nitrogen from forested watersheds in the Oregon Coast Range: The role of $\mathrm{N}_{2}$-fixing red alder. Ecosystems 6:773-785.

Cuddihy, L. W., and C. P. Stone. 1990. Alteration of native Hawaiian vegetation: Effects of humans, their activities and introductions. University of Hawai'i Press, Honolulu.

Ferreira, V., V. Gulis, and M. A. S. Graca. 2006. Whole-stream nitrate addition affects litter decomposition and associated fungi but not invertebrates. Oecologia (Berl.) 149:718-729.

Finlay, J. C. 2001. Stable-carbon-isotope ratios of river biota: Implications for energy flow in lotic food webs. Ecology 82:10521064.

. 2004. Patterns and controls of lotic algal stable carbon isotope ratios. Limnol. Oceanogr. 49:850-861.

Finlay, J. C., M. E. Power, and G. Cabana. 1999. Effects of water velocity on algal carbon isotope ratios: Implications for river food web studies. Limnol. Oceanogr. 44:1198-1203.

Fry, B., and E. Sherr. 1984. $\delta^{13} \mathrm{C}$ measure- 
ments as indicators of carbon flow in marine and freshwater ecosystems. Contrib. Mar. Sci. 27:13-47.

Goldman, C. R. 1961. The contribution of alder trees (Alnus tenuifolia) to the primary production of Castle Lake, California. Ecology 42:282-288.

Gulis, V., V. Ferreira, and M. A. S. Graca. 2006. Stimulation of leaf litter decomposition and associated fungi and invertebrates by moderate eutrophication: Implications for stream assessment. Freshwater Biol. 51:1655-1669.

Hughes, F. R., and J. S. Denslow. 2005. Invasion by a $\mathrm{N}_{2}$-fixing tree alters function and structure in wet lowland forests of Hawaii. Ecol. Appl. 15:1615-1628.

Juvik, S. P., and J. O. Juvik, eds. 1998. Atlas of Hawai'i. 3rd ed. Department of Geography, University of Hawai'i at Hilo. University of Hawai'i Press, Honolulu.

Laperriere, J. 1995. Riffle algae ecology of small streams during the rainy season: Islands of Hawaii, Maui, and Oahu. Trop. Ecol. 36:59-72.

Larned, S. T., C. T. Chong, and N. Punewai. 2000. Detrital fruit processing in a Hawaiian stream ecosystem. Biotropica 33:241248.

Maberly, S. C., J. A. Raven, and A. M. Johnston. 1992. Discrimination between ${ }^{12} \mathrm{C}$ and ${ }^{13} \mathrm{C}$ by marine plants. Oecologia (Berl.) 91:481-492.

Maguire, C., and J. Grey. 2006. Determination of zooplankton dietary shift following a zebra mussel invasion, as indicated by stable isotope analysis. Freshwater Biol. 51:1310-1319.

Mantel, S. K., M. Salas, and D. Dudgeon. 2004. Foodweb structure in a tropical Asian forest stream. J. North Am. Benthol. Soc. 23:728-755.

McCarthy, J. M., C. L. Hein, J. D. Olden, and M. J. Vander Zanden. 2006. Coupling long-term studies with meta-analysis to investigate impacts of invasive crayfish on zoobenthic communities. Freshwater Biol. 51:224-235.

Neill, C., L. A. Deegan, S. M. Thomas, and C. C. Cerri. 2001. Deforestation for pastures alters nitrogen and phosphorus in small Amonzonian streams. Ecol. Appl. 11:1817-1828.

Nelson, R. E. 1965. A record of forest planting in Hawaii. U.S. For. Serv. Resour. Bull. PSW-14.

Peterson, B. J., and B. Fry. 1987. Stable isotopes in ecosystem studies. Annu. Rev. Ecol. Syst. 18:293-320.

Phillips, D. L., and J. W. Gregg. 2003. Source partitioning using stable isotopes: Coping with too many sources. Oecologia (Berl.) 136:261-269.

Piccolo, J. J., and M. S. Wipfli. 2002. Does red alder (Alnus rubra) in upland riparian forests elevate macroinvertebrate and detritus export from headwater streams to downstream habitats in southwestern Alaska. Can. J. Fish. Aquat. Sci. 59:503513.

Rooker, J. R., J. P. Turner, and S. A. Holt. 2006. Trophic ecology of Sargassumassociated fishes in the Gulf of Mexico determined from stable isotopes and fatty acids. Mar. Ecol. Prog. Ser. 313:249-259.

Scott, E. E., S. S. Perakis, and D. E. Hibbs. 2008. $\delta^{15} \mathrm{~N}$ patterns of douglas-fir and red alder riparian forests in the Orgeon Coast Range. For. Sci. 54:140-147.

Vander Zanden, M. J., J. M. Casselman, and J. B. Rasmussen. 1999. Stable isotope evidence for the food web consequences of species invasions in lakes. Nature (Lond.) 401:464-467.

Vitousek, P. M. 2004. Nutrient cycling and limitation: Hawaii as a model system. Princeton University Press, Princeton, New Jersey.

Volk, C. J., P. M. Kiffney, and R. L. Edmons. 2003. Role of riparian red alder in the nutrient dynamics of coastal streams of the Olympic Peninsula, Washington, USA. Am. Fish. Soc. Symp. 34:213-225.

Wagner, W. A., D. R. Herbst, and S. H. Sohmer. 1999. Manual of the flowering plants of Hawai'i. University of Hawai' $i$ Press, Honolulu.

Wallace, J. B., S. L. Eggert, J. L. Meyer, and J. R. Webster. 1997. Multiple trophic levels of a forest stream linked to terrestrial litter inputs. Science (Washington, D.C.) 277:102-104. 
Webster, J. R., E. F. Benfield, T. P. Ehrman, M. A. Schaeffer, J. L. Tanks, J. J. Hutchens, and D. J. D'angelo. 1999. What happens to allochthonous material that falls into streams? A synthesis of new and published information from Coweeta. Freshwater Biol. 41:687-705.

Wipfli, M. S., and D. P. Gregovich. 2002. Export of invertebrates and detritus from fishless headwater streams in southwestern Alaska: Implications for downstream salmonid production. Freshwater Biol. 47:957-969.

Wondzell, S. W., and F. J. Swanson. 1996. Seasonal and storm dynamics of the hyporheic zone of a 4th-order mountain stream. II: Nitrogen cycling. J. North Am. Benthol. Soc. 15:20-34.

Wright, R. F., and L. Rasmussen. 1998. Introduction to NITREX and EXMAN projects. For. Ecol. Manage. 101:1-7. 
